EXTENDED REPORT

\title{
Endothelial nitric oxide synthase gene polymorphisms in Behçet's disease and rheumatic diseases with vasculitis
}

\author{
J U Kim, H K Chang, S S Lee, J W Kim, K T Kim, S W Lee, W T Chung
}

Ann Rheum Dis 2003;62:1083-1087

See end of article for authors' affiliations

Correspondence to:

Dr H K Chang, Division of

Rheumatology,

Department of Internal

Medicine, College of

Medicine, Dankook

University, 16-5 Anseo-

Dong, Cheonan,

Chungcheongnamdo,

330-715, South Korea;

hanks22@dankook.ac.kr

Accepted 12 March 2003
Objective: To assess potential associations between Korean Behçet's disease (BD) or other rheumatic diseases with vasculitis and two polymorphisms of the endothelial nitric oxide synthase (eNOS) gene, which include the Glu298Asp polymorphism in exon 7 and a variable number of tandem repeats (VNTR) polymorphism in intron 4.

Methods: 65 patients with BD, 27 with rheumatic diseases with vasculitis, and 80 controls were studied. Analyses of the Glu298Asp polymorphism in exon 7 and VNTR polymorphism in intron 4 of the eNOS gene were made by the polymerase chain reaction (PCR)-restriction fragment length polymorphism technique and PCR genotyping, respectively. Additionally, HLA-B51 typing was performed in the BD group and controls by a two step PCR sequence-specific primers method.

Results: Significant differences in Glu298Asp genotype frequencies were found between the BD or vasculitis groups and the controls $\left(B D\right.$ group $v$ controls: $p_{\text {corr }}=0.006$; vasculitis group $v$ controls: $p<0.001$ ). The Asp298 frequency was much higher in the BD and vasculitis groups than in the controls. Even after stratification of the BD group based on the results of HLA-B51 testing, a significant association of the Glu298Asp polymorphism was still found $(p=0.002$, Mantel-Haenszel weighted odds ratio 4.3, 95\% confidence interval 1.7 to 10.9). Distribution of the genotype frequencies in two eNOS gene polymorphisms was similar in connective tissue diseases-associated vasculitis and primary vasculitic syndromes. In contrast, distribution of alleles and genotypes of VNTR polymorphism did not differ between $\mathrm{BD}$ or vasculitis groups and the controls.

Conclusion: The Glu298Asp polymorphism in exon 7 of the eNOS gene seems to be a susceptibility gene for Korean BD and other rheumatic diseases.
$\mathrm{N}$ itric oxide (NO) is synthesised, via L-arginine oxidation, by a family of nitric oxide synthases (NOS), ${ }^{12}$ in which three isoforms have been identified: two constitutive, the neuronal NOS (nNOS, NOS-I) and endothelial (eNOS, NOS-III), and one inducible NOS (iNOS, NOS-II). The eNOS in the endothelium generates small amounts of $\mathrm{NO}$ in response to receptor stimulation (for example, acetylcholine, bradykinin) or shear stress, which contributes to regulate vascular tone. Under physiological conditions, NO does not cause tissue damage, because it is rapidly cleared by reaction with oxyhaemoglobin. In contrast, the iNOS induced by endotoxin and inflammatory cytokines in the infectious or inflammatory disorders results in very high NO production, which can destroy host tissues and modify the course of diseases. ${ }^{3-7}$

The eNOS gene is located on chromosome 7q35-36 and comprises 26 exons spanning $21 \mathrm{~kb} .{ }^{8}$ When a variant of this gene causes deficient NOS, disease processes may ensue. Many studies have been carried out to determine the relevance between DNA variants in the eNOS gene and vascular diseases. To date, a variety of vascular diseases, which include coronary artery disease (CAD) or myocardial infarction (MI), hypertension, stroke, and renal diseases, have been associated with the eNOS gene polymorphisms. ${ }^{9-14}$ However, the results show interracial inconsistencies, and the specific genetic variants may be relevant only to restricted populations. $^{9}$

The histological hallmark in Behçet's disease (BD) is known to be a vasculitis. Any sized vessel lesions such as small vessel vasculitis, large venous or arterial lesions can be involved, and venous lesions, including superficial thrombophlebitis and deep vein thrombosis, are a characteristic manifestation of the disease. ${ }^{15}{ }^{16}$ Although the definite pathogenic mechanism for the vascular lesions in BD remains unclear, endothelial dysfunction is thought to have an important role in the development of these lesions. ${ }^{17-19}$ Recently, it was shown that brachial artery flow mediated dilatation was impaired in BD. ${ }^{18}$ Because flow mediated dilatation is endothelium dependent and mediated largely by the release of endothelial $\mathrm{NO}^{20}$ the impairment of endothelium dependent, flow mediated dilatation suggests a decreased endothelial NO activity, which may contribute to vascular lesions in $\mathrm{BD}$. In addition, a recent study reported that the Glu298Asp polymorphism of the eNOS gene was associated with BD susceptibility in an Italian population. ${ }^{21}$

On the other hand, various chronic inflammatory rheumatic disorders, such as systemic lupus erythematosus (SLE) and rheumatoid arthritis (RA), have higher cardiovascular mortality than age matched populations. ${ }^{22-25}$ It has been reported that the endothelium dependent, flow mediated dilatation was also impaired in patients with SLE as well as patients with primary necrotising vasculitis, such as Wegener's granulomatosis, polyarteritis nodosa, ChurgStrauss syndrome, and Kawasaki disease. ${ }^{26-28}$ However, to the best of our knowledge, studies on the association between polymorphisms of the eNOS gene and chronic rheumatic diseases with vasculitis have not been described.

\footnotetext{
Abbreviations: $B D$, Behçet's disease; $C A D$, coronary artery disease; $C l$, confidence interval; CTD, connective tissue disease; eNOS, endothelial nitric oxide synthase; $\mathrm{MI}$, myocardial infarction; $\mathrm{NO}$, nitric oxide; $\mathrm{OR}$, odds ratio; PCR, polymerase chain reaction; RA, rheumatoid arthritis; SLE, systemic lupus erythematosus; VNTR, variable number of tandem repeats
} 
Therefore we conducted a study for the potential associations between Korean BD or other rheumatic diseases with vasculitis and two commonly studied polymorphisms of the eNOS gene, which include the Glu298Asp polymorphism in exon 7 and a variable number of tandem (27 base pair (bp)) repeats (VNTR) polymorphism in intron 4.

\section{PATIENTS AND METHODS}

\section{Subjects}

The study groups included 65 patients with BD (22 men, 43 women) who fulfilled the criteria of the International Study Group, ${ }^{29} 27$ patients with rheumatic diseases with vasculitis (vasculitis group; 9 men, 18 women) who were classified according to internationally accepted criteria for each disease, as well as 80 healthy controls ( 30 men, 50 women). The mean (SD) ages of the BD group, vasculitis group, and controls were 38.6 (8.5) years, 35.0 (11.9) years, and 40.6 (11.6) years, respectively. All the subjects were ethnically homogenous Koreans who were unrelated.

The age at onset was defined as the time for which the patient had fulfilled the ISG criteria, which in the BD group was 32.5 (8.7) years. Table 1 summarises the clinical features of the patients with BD. In addition, the presence of one or more of the following clinical features during the course of the disease was regarded as a severe manifestation, as described in our previous study: posterior uveitis or retinal vasculitis, gastrointestinal ulcerations with bleeding or perforation, major organ involvement, or major vessel involvement. ${ }^{30}$ On the other hand, the vasculitis group consisted of 17 patients with connective tissue diseases (CTD)-associated vasculitis ( 15 with SLE and 2 with RA) and 10 patients with primary vasculitic syndromes (3 with Takayasu's arteritis, 3 with Henoch-Schönlein purpura, 2 with polyarteritis nodosa, 1 with Wegener's granulomatosis, and 1 with Churg-Strauss syndrome). In the CTD-associated vasculitis, biopsy proven cases or patients with clinical evidence of vasculitis, such as digit gangrene or vasculitis affecting visceral organs, were included. Patients with hypertension, CAD, or end stage renal disease were excluded from this study. Informed consent was obtained from all the subjects.

\section{DNA extraction}

Genomic DNA was isolated from peripheral blood leucocytes by the Chelex extraction method. ${ }^{31}$

Analysis of the Glu298Asp polymorphism in exon 7 of the eNOS gene

The presence of Glu298Asp variants was determined in all the subjects by polymerase chain reaction (PCR)restriction fragment length polymorphism analysis. A set of primers (5'-AAGGCAGGAGACAGTGGATGGA-3' and 5' -

Table 1 The clinical features of 65 patients with Behçet's disease

\begin{tabular}{ll}
\hline Clinical features & Number of patients (\%) \\
\hline Oral ulcerations & $65(100)$ \\
Skin lesions & $60(92)$ \\
Genital ulcerations & $55(85)$ \\
Pathergy reactions & $20(31)$ \\
Ocular lesions & $18(28)$ \\
Arthritis & $15(23)$ \\
Intestinal lesions & $12(18)$ \\
Vascular lesions & $12(18)$ \\
Central nervous system lesions & $5(8)$ \\
HLA-B51 & $33(51)$ \\
Epididymitis & $1(2)$ \\
\hline
\end{tabular}

CCCAGTCAATCCCTTTGGTGCTCA-3') was used to amplify the $248 \mathrm{bp}$ fragment including the Glu298Asp mutation site. ${ }^{10}$ The amplified PCR products were digested with the restriction enzyme, BanII, as recommended by the supplier (Roche Diagnostics, Mannheim, Germany). DNA fragments were separated by electrophoresis on 2\% agarose gel. The Asp298 variant had no cutting site for BanII by G to T substitution at nucleotide position 894 of the eNOS gene, so that the 248 bp PCR product was not cleaved into $163 \mathrm{bp}$ and $85 \mathrm{bp}$ fragments, in contrast with the wild-type Glu298 (fig 1).

\section{Analysis of the VNTR polymorphism in intron 4 of the} eNOS gene

Detection of VNTR polymorphism was performed in all the subjects by PCR genotyping. Two primers (5'AGGCCCTATGGTAGTGCCTT-3' and 5'-TCTCTTAGTGCTGT GGTCAC-3'), which were based on the sequences flanking VNTR in intron 4 of the eNOS gene, were used to amplify the corresponding DNA fragment. ${ }^{12}$ The PCR products were separated by $2.5 \%$ agarose gel electrophoresis. The $420 \mathrm{bp}$ wild-type product contained five 27 bp repeats (the " $\mathrm{b}$ " allele), and the $393 \mathrm{bp}$ mutant type contained four $27 \mathrm{bp}$ repeats (the "a" allele) (fig 2 ).

\section{Analysis of HLA-B5 1 antigen}

HLA-B51 typing was performed in the BD group and controls by a two step PCR sequence-specific primers method, as described in our previous study. ${ }^{32}$

\section{Statistical analysis}

The data were analysed using the SPSS statistical package program, version 10.0 for Windows (SPSS Inc, Chicago, IL, USA). The statistical significance was evaluated by $\chi^{2}$ test or $t$ test when indicated. Values of $\mathrm{p}<0.05$ were considered significant, and these were corrected in certain cases by multiplying the values by the number of alleles investigated. The results were re-evaluated by multiple logistic regression analysis and the odds ratio (OR) was estimated where necessary. The association between the eNOS gene polymorphisms and $\mathrm{BD}$, after stratification of the patients according to the results of HLA-B51 testing to exclude the

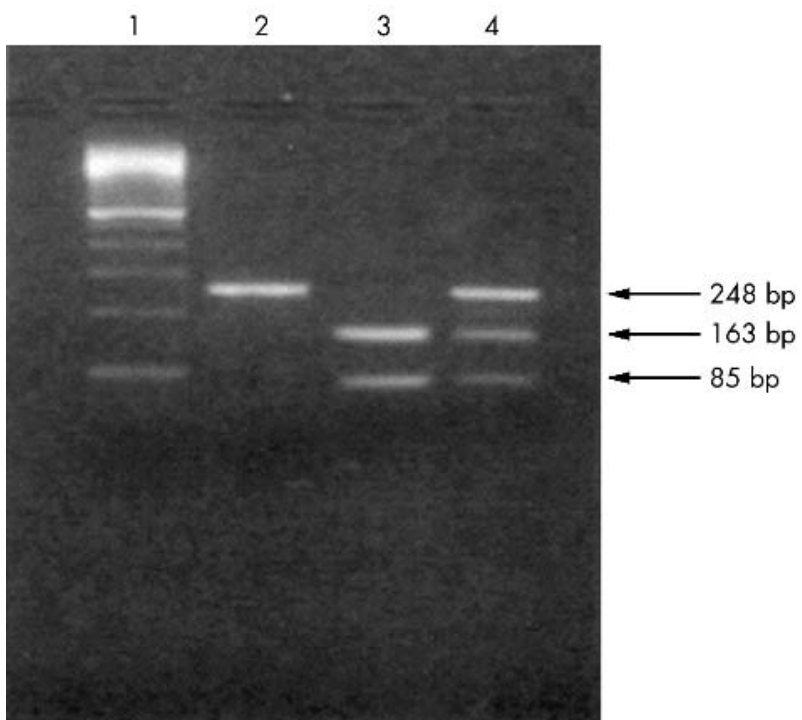

Figure 1 Analysis of the Glu298Asp polymorphism in exon 7 of the eNOS gene. Three kinds of restriction fragments are shown after digestion with Banll: lane 1, size marker; lane 2, homozygote (Asp/Asp); lane 3, homozygote (Glu/Glu) lane 4, heterozygote (Glu/Asp). 


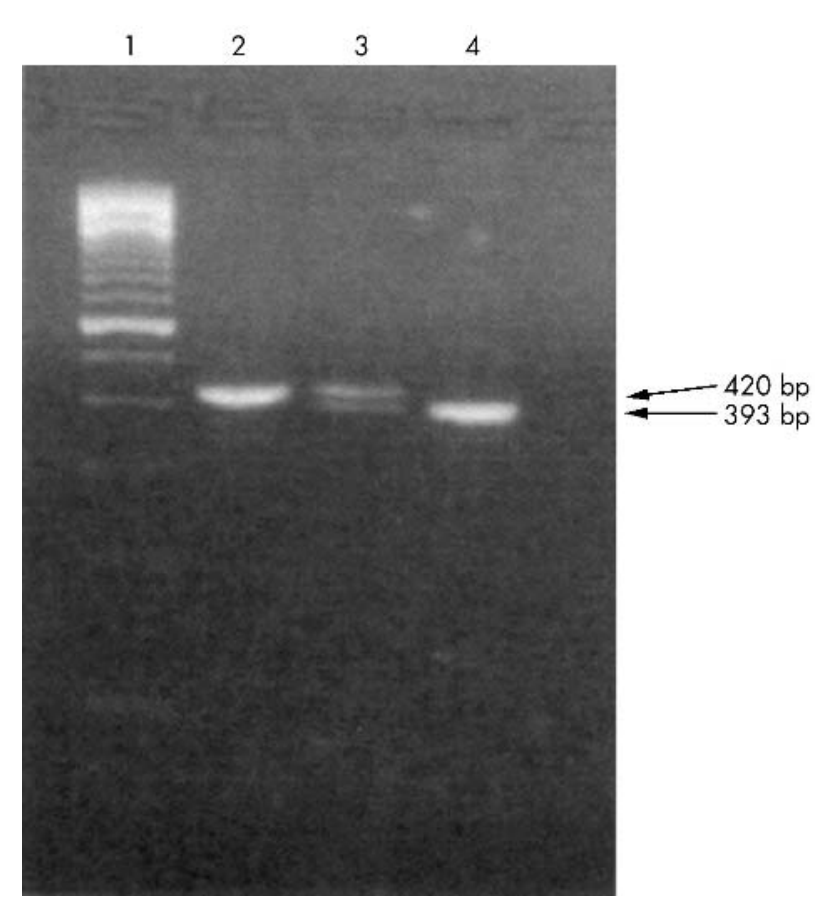

Figure 2 Analysis of the VNTR polymorphism in intron 4 of the eNOS gene. The band of $420 \mathrm{bp}$ indicates five repeats and the band of $393 \mathrm{bp}$ indicates four repeats of the $27 \mathrm{bp}$ : lane 1, size marker; lane 2, wild type $(4 b / b)$; lane 3 , four and five repeats heterozygote $(4 b / a)$; lane 4 , four repeats homozygote $(4 a / a)$.

possible confounding effect of HLA-B51, was estimated by calculation of the Mantel-Haenszel weighted OR.

\section{RESULTS}

Table 2 shows the genotype frequencies of the eNOS gene polymorphisms in each study group. There was a significant difference in the frequencies of the Glu298Asp genotypes in exon 7 between the BD group or vasculitis group and the controls (BD group $v$ controls: $\mathrm{p}=0.002, \mathrm{p}_{\text {corr }}=0.006$; vasculitis group $v$ controls: $\mathrm{p}<0.001)$. The frequencies of the Glu298Asp heterozygote (Glu/Asp) were much higher in the $\mathrm{BD}$ and vasculitis groups than in the controls. Of interest, the Glu298Asp homozygote (Asp/Asp) was found only in three patients of the vasculitis group. In contrast, the genotype frequencies of the VNTR polymorphism in intron 4 did not significantly differ between the BD group or vasculitis group and the controls.

Table 2 The genotype frequencies of eNOS gene polymorphisms in the Behçet's disease (BD) group $(n=65)$, vasculitis group $(n=27)$, and in controls $(n=80)$

\begin{tabular}{lcll}
\hline Genotype & $\begin{array}{l}\text { Controls } \\
\text { No (\%) }\end{array}$ & $\begin{array}{l}\text { BD group } \\
\text { No (\%) }\end{array}$ & $\begin{array}{l}\text { Vasculitis group } \\
\text { No (\%) }\end{array}$ \\
\hline $\begin{array}{l}\text { 27 bp repeats polymorphism } \\
4 \mathrm{a} / \mathrm{a}\end{array}$ & $1(1)$ & 0 & 0 \\
$4 \mathrm{~b} / \mathrm{a}$ & $17(21)$ & $13(20)$ & $4(15)$ \\
$4 \mathrm{~b} / \mathrm{b}$ & $62(78)$ & $52(80)^{*}$ & $23(85) \dagger$ \\
Glu298Asp polymorphism & 0 & 0 & $3(11)$ \\
Asp/Asp & $9(11)$ & $21(32)$ & $8(30)$ \\
Glu/Asp & $71(89)$ & $44(68) \ddagger$ & $16(59) \S$ \\
Glu/Glu & & & \\
\hline
\end{tabular}

For the 27 bp repeats polymorphism: ${ }^{*} p=0.604$ between BD group and controls; $\mathrm{tp}=0.356$ between the vasculitis group and controls. For the Glu298Asp polymorphism: $\ddagger p=0.002$ ( $p_{\text {corr }}=0.006$ ) between the $\mathrm{BD}$ group and controls; $\S p<0.001$ between the vasculitis group and controls.
Table 3 The allele frequencies of eNOS gene polymorphisms in the Behçet's disease (BD) group $(n=130)$, vasculitis group $(n=54)$, and in controls $(n=160)$

\begin{tabular}{lccl}
\hline Allele & $\begin{array}{l}\text { Controls } \\
\text { No }(\%)\end{array}$ & $\begin{array}{l}\text { BD group } \\
\text { No (\%) }\end{array}$ & $\begin{array}{l}\text { Vasculitis group } \\
\text { No (\%) }\end{array}$ \\
\hline $\begin{array}{l}\text { 27 bp repeats polymorphism } \\
4 \mathrm{a}\end{array}$ & $19(12)$ & $13(10)$ & $4(7)$ \\
$4 \mathrm{~b}$ & $141(88)$ & $117(90)^{*}$ & $50(93) \dagger$ \\
$\begin{array}{l}\text { Glu298Asp polymorphism } \\
\text { Asp }\end{array}$ & $9(6)$ & $21(16)$ & $14(26)$ \\
Glu & $151(94)$ & $109(84) \ddagger$ & $40(74) \S$ \\
\hline
\end{tabular}

For the 27 bp repeats polymorphism: ${ }^{*} p=0.612$ between the BD group and controls; ${ }^{\dagger} p=0.453$ between the vasculitis group and controls. For the Glu298Asp polymorphism: $\neq p=0.003$ ( $p_{\text {corr }}=0.006$ ) between the $\mathrm{BD}$ group and controls; $\$ p<0.001$ between the vasculitis group and controls.

Table 3 lists the allele frequencies of the eNOS gene polymorphisms. The distribution of the Glu298Asp alleles differed significantly between the BD group or vasculitis group and the controls (BD group $v$ controls: $\mathrm{p}=0.003$, $\mathrm{p}_{\text {corr }}=0.006$; vasculitis group $v$ controls: $\left.\mathrm{p}<0.001\right)$. In addition, the frequencies of Asp298 were much higher in the $\mathrm{BD}$ and vasculitis groups than in the controls. Furthermore, the OR values for development of BD or rheumatic diseases with vasculitis in Koreans with Asp298 were 3.2 (95\% confidence interval (CI) 1.4 to 7.3 ) or $5.9(95 \%$ CI 2.4 to 14.5), respectively. However, in the case of the alleles of the VNTR polymorphism, no significant differences were found between the BD group or vasculitis group and the controls.

The frequency of HLA-B51 antigen was significantly higher in the BD groups than in the controls $(50.8 \% \vee 23.8 \%$, $\mathrm{p}=0.001$, OR $3.3,95 \%$ CI 1.6 to 6.7 ). Even after stratification of the BD patients according to the results of HLA-B51 testing, the Glu298Asp polymorphism still correlated significantly with $\mathrm{BD}\left(\mathrm{p}=0.002, \chi^{2}\right.$ 8.7, Mantel-Haenszel weighted OR $4.3,95 \%$ CI 1.7 to 10.9). In addition, the distribution of genotype frequencies in the Glu298Asp and VNTR gene polymorphisms was similar between CTDassociated vasculitis and primary vasculitic syndromes (table 4).

In the associations between the two eNOS gene polymorphisms and clinical features presented in table 1 , the frequencies of Glu298Asp and VNTR variant genotypes were

Table 4 The genotype frequencies of eNOS gene polymorphisms in primary vasculitic syndromes $(n=10)$ and vasculitis associated with connective tissue diseases $(n=17)$

\begin{tabular}{lll}
\hline & $\begin{array}{l}\text { Primary vasculitic } \\
\text { syndromes } \\
\text { No (\%) }\end{array}$ & $\begin{array}{l}\text { Connective tissue } \\
\text { disease associated } \\
\text { vasculitis } \\
\text { No }(\%)\end{array}$ \\
\hline $\begin{array}{l}\text { Genotype } \\
4 \mathrm{a} / \mathrm{a} p \text { repeats polymorphism }\end{array}$ & 0 & 0 \\
$4 \mathrm{~b} / \mathrm{a}$ & $1(10)$ & $3(18)$ \\
$4 \mathrm{~b} / \mathrm{b}$ & $9(90)$ & $14(82)^{*}$ \\
Glu298Asp polymorphism & $1(10)$ & $2(12)$ \\
$\begin{array}{l}\text { Asp/Asp } \\
\text { Glu/Asp }\end{array}$ & $3(30)$ & $5(29)$ \\
Glu/Glu & $6(60)$ & $10(59) \dagger$ \\
\hline
\end{tabular}

For the 27 bp repeats polymorphism: ${ }^{*} \mathrm{p}=1.0$ between primary vasculitic syndromes and vasculitis associated with connective tissue disease. For the Glu298Asp polymorphism: $\uparrow p=0.916$ between primary vasculitic syndromes and vasculitis associated with connective tissue disease. 
significantly higher only in patients with BD with vascular lesions $(p=0.038 ; p=0.033$, respectively), but the significance was lost after multiple logistic regression analysis using the Enter method with other clinical variables of BD (data not shown). On the other hand, the mean (SD) age at onset in patients with BD with Glu298Asp or VNTR variant genotypes was comparable with that in the patients without variant genotypes (Glu298Asp: 32.8 (8.2) years $v 32.4$ (9.0) years; VNTR: 32.0 (8.8) years $v 32.7$ (8.7) years). In addition, severe manifestations were found in 24 patients in the BD group. Although the frequencies of Glu298Asp or VNTR variant genotypes in the patients with severe manifestations were higher than those in the patients without these manifestations, they did not reach significance (Glu298Asp: 41.7\% v 26.8\%, p>0.05; VNTR: 29.2\% v 14.6\%, $\mathrm{p}>0.05$ ).

\section{DISCUSSION}

A number of polymorphisms have been identified in the promoter region, exons, and introns of the eNOS gene, but the findings have shown interracial inconsistencies. Until now, the most studied eNOS gene polymorphisms have included the Glu298Asp polymorphism in exon 7 and VNTR polymorphism in intron 4, both of which may contribute to the development of various vascular diseases, including CAD or MI, coronary spasm, hypertension, stroke, and renal diseases. ${ }^{9}$ In our study the Glu298Asp polymorphism appeared to be a susceptibility marker for Korean BD and other rheumatic diseases with vasculitis. Whereas our study showed that the OR (95\% CI) values of Asp298 were 3.2 ( 1.4 to 7.3 ) for $\mathrm{BD}$ and 5.9 (2.4 to 14.5) for rheumatic diseases with vasculitis, a previous Italian study showed that this value for BD was 2.1 (1.5 to 3.3). ${ }^{21}$ In our study groups the frequencies of homozygote variants of the eNOS gene polymorphisms - that is, Asp/Asp and 4a/a, were very low, which was also found in other studies, ${ }^{10-13}$ with the exception of one. ${ }^{21}$

Previously, it was proposed that two polymorphisms of the eNOS gene, the Glu298Asp polymorphism in exon 7 and VNTR polymorphism in intron 4 , might be associated with the altered function of this gene. ${ }^{33-37}$ Such functional DNA variants in the eNOS gene may lead to a change in eNOS expression and enzymatic activity. ${ }^{9}$ On the other hand, recent studies have shown that endothelium dependent, flow mediated vasodilatation, mainly mediated by the release of endothelial $\mathrm{NO}^{20}$ was impaired in $\mathrm{BD}, \mathrm{SLE}$, and primary necrotising vasculitic syndromes. ${ }^{18}{ }^{26-28}$ Thus, it seems reasonable to assume that this altered eNOS expression resulting from the gene polymorphisms reduces the release of endothelial NO, which in turn contributes to the endothelial dysfunction seen in BD and other rheumatic diseases with vasculitis. Furthermore, the impaired production of basal NO and associated endothelial dysfunction may predispose to thrombosis or atherosclerosis related disorders. ${ }^{98}$ This proposed pathogenic mechanism appears to be supported by our study, which showed a significant correlation between the Glu298Asp polymorphism of the eNOS gene and BD or rheumatic diseases with vasculitis. In future studies it will be necessary to investigate the association between eNOS gene polymorphisms and endothelium dependent, flow mediated vasodilatation.

It is known that up to $25 \%$ of patients with BD may have systemic venous thrombosis. ${ }^{39}$ Endothelial dysfunction is thought to play an important part in the development of thrombosis in these patients. ${ }^{17-19}$ On the other hand, the incidence of MI has been estimated to be at least 50 -fold higher in young patients with SLE than in age matched controls, ${ }^{22}$ and occlusive coronary disease in these patients may result from atherosclerosis, thrombosis, or vasculitis. ${ }^{25}$
Moreover, Shimasaki et al demonstrated that the Glu298Asp polymorphism of the eNOS gene was a significant risk factor for MI, independently of the traditional CAD risk factors, such as hypertension, smoking, hyperlipidaemia, and diabetes mellitus. ${ }^{10}$ Although only patients with SLE who had vasculitis were included in the current study, we showed that the frequencies of Glu298Asp variant genotypes were increased to the same extent in patients with CTD-associated vasculitis and in patients with primary vasculitic syndromes. However, published reports of controlled studies for cardiovascular mortality or CAD in rheumatic diseases other than SLE are few. As far as we are aware, this is the first study to correlate the eNOS gene polymorphisms with rheumatic diseases with vasculitis.

Although the exact pathogenesis for BD is not completely understood, it has been suggested that the disease is triggered in genetically susceptible people by environmental factors, such as infectious agents. To date, HLA-B51 has been implicated as the candidate gene showing the strongest association with BD. ${ }^{15}{ }^{32} 40$ Recently, Salvarani et al showed that the Glu298Asp polymorphism of the eNOS gene was another susceptibility gene for BD that was independent of HLA-B51 in Italian populations. The association between the polymorphisms of this gene and clinical manifestations of BD was not found in their study. ${ }^{21}$ Our findings are similar to those obtained in the Italian study, and the initial statistical significance between eNOS gene polymorphisms and patients with BD with vascular lesions was lost when multiple logistic regression analysis was performed. In addition, no significant associations were found between these polymorphisms and the age at onset or severe manifestations in the BD group.

Excessive NO production occurs during various rheumatic diseases, including SLE, RA, Sjögren's syndrome, vasculitis, and osteoarthritis. ${ }^{3}$ On the other hand, there have been conflicting reports about serum NO concentrations in patients with BD. Some authors have reported significantly higher NO levels in patients with active disease than in patients with inactive disease or control subjects. ${ }^{41-43}$ Other researchers have described the opposite and argued that decreased NO levels in the active stage might be attributable to the rapid transformation of NO to peroxynitrites. ${ }^{44}$ In any case, we believe that the increased NO levels found in a variety of rheumatic diseases, such as BD and CTD, result from the induction of iNOS expression by inflammatory stimuli, irrespective of the physiological NO production by eNOS.

In summary, the Glu298Asp polymorphism appeared to be a susceptibility gene for Korean BD and other rheumatic diseases, including CTD-associated vasculitis and primary vasculitic syndromes. Because the association between eNOS gene polymorphisms and vascular diseases varies according to race, this study should be carried out in other ethnic populations. Because only patients with SLE who manifested vasculitis were recruited in the current study, further studies are warranted in other patients with SLE who have no clinical evidence of vasculitis. Moreover, it will be necessary to clarify whether there is an association between eNOS gene polymorphisms and other inflammatory rheumatic diseases without vasculitis, such as ankylosing spondylitis. On the other hand, replacement therapy to alleviate the NO or eNOS deficit has been considered in disease states where the effective levels of endothelial NO are decreased. ${ }^{6}$ In this respect, L-arginine, which is a precursor of NO, has been shown to improve endothelium dependent vasodilatation in hypercholesterolaemic humans. ${ }^{46}$ Therapeutic modalities that restore deficiencies in NO or eNOS may be considered in the treatment of $\mathrm{BD}$ or rheumatic diseases with vasculitis. 


\section{Authors' affiliations}

J U Kim, Department of Laboratory Medicine, Ulsan University, Kangnung, South Korea

H K Chang, Division of Rheumatology, Department of Internal Medicine, Dankook University, Cheonan, South Korea

S S Lee, Division of Rheumatology, Department of Internal Medicine,

Chonnam National University Medical School, Kwangju, South Korea

J W Kim, Department of Laboratory Medicine, Dankook University,

Cheonan, South Korea

K T Kim, Department of Emergency Medicine, Dankook University,

Cheonan, South Korea

S W Lee, W T Chung, Division of Rheumatology, Department of Internal

Medicine, Dong-A University, Busan, South Korea

\section{REFERENCES}

1 Schmidt HHHW, Nau H, Wittfoht W, Gerlach J, Prescher KE, Klein MM, et al. Arginine is a physiological precursor of endothelium-derived nitric oxide. Eur J Pharmacol 1988;154:213-16.

2 Palmer RM, Ashton DS, Moncada S. Vascular endothelial cells synthesize nitric oxide from L-arginine. Nature 1988;333:664-6.

3 Clancy RM, Amin AR, Abramson SB. The role of nitric oxide in inflammation and immunity. Arthritis Rheum 1998;41:1141-51.

4 Stichtenoth DO, Frölich JC. Nitric oxide and inflammatory joint diseases. Br J Rheumatol 1998:37:246-57.

5 Schmidt HHHW, Walter U. NO at work. Cell 1994:78:919-25.

6 Lefer AM. Nitric oxide: nature's naturally occurring leukocyte inhibitor. Circulation 1997:95:553-4.

7 Beckman JS, Koppenol WH. Nitric oxide, superoxide, and peroxynitrite: the good, the bad, and ugly. Am J Physiol 1996;271:C1424-37.

8 Marsden PA, Heng HH, Scherer SW, Stewart RJ, Hall AV, Shi XM, et al. Structure and chromosomal localization of the human constitutive endothelial nitric oxide synthase gene. J Biol Chem 1993;268:17478-88.

9 Wang XL, Wang J. Endothelial nitric oxide synthase gene sequence variations and vascular disease. Mol Genet Metab 2000;70:241-51.

10 Shimasaki Y, Yasue H, Yoshimura M, Nakayama M, Kugiyama K, Ogawa H, et al. Association of the missense Glu298Asp variant of the endothelial nitric oxide synthase gene with myocardial infarction. J Am Coll Cardio 1998:31:1506-10.

11 Uwabo J, Soma M, Nakayama T, Kanmatsuse K. Association of a variable number of tandem repeats in the endothelial constitutive nitric oxide synthase gene with essential hypertension in Japanese. Am J Hyperten 1998:11:125-8.

12 Wang XL, Sim AS, Badenhop RF, McCredie RM, Wilcken DE. A smokingdependent risk of coronary artery disease associated with a polymorphism of the endothelial nitric oxide synthase gene. Nat Med 1996;2:41-5.

13 Akar N, Akar E, Cin S, Deda G, Avcu F, Yalcin A. Endothelial nitric oxide synthase intron 4, 27 bp repeat polymorphism in Turkish patients with deep vein thrombosis and cerebrovascular accidents. Thromb Res 1999:94:63-4.

14 Yokoyama K, Tsukada T, Matsuoka H, Hara S, Yamada A, Kawaguchi Y. High accumulation of endothelial nitric oxide synthase (ecNOS): a gene polymorphism in patients with end-stage renal disease. Nephron 1998:79:360-1.

15 Sakane T, Takeno M, Suzuki N, Inaba G. Behçet's disease. N Engl J Med 1999;341:1284-91

16 Koc Y, Gullu I, Akpek G, Akpolat T, Kansu E, Kiraz S, et al. Vascular involvement in Behcet's disease. J Rheumatol 1992:19:402-10.

17 Schmitz-Huebner U, Knop J. Evidence for an endothelial cell dysfunction in association with Behçet's disease. Thromb Res 1984;34:277-85.

18 Chambers JC, Haskard DO, Kooner JS. Vascular endothelial function and oxidative stress mechanisms in patients with Behçet's syndrome. J Am Coll Cardiol 2001:37:517-20.

19 Haznedaroglu IC, Ozcebe OI, Ozdemir O, Celik I, Dundar SV, Kirazli S. Impaired haemostatic kinetics and endothelial function in Behçet's disease. $J$ Intern Med 1996;240:181-7.

20 Joannides $R$, Haefeli WE, linder L, Richard V, Bakkali EH, Thuillez $C$, et al. Nitric oxide is responsible for flow-dependent dilatation of human peripheral conduit arteries in vivo. Circulation 1995;91:1314-19.

21 Salvarani C, Boiardi L, Casali B, Olivieri I, Ciancio G, Cantini F, et al. Endothelial nitric oxide synthase gene polymorphisms in Behçet's disease. $J$ Rheumatol 2002;29:535-40.

22 Manzi S, Meilahn EN, Rairie JE, Conte CG, Medsger TA Jr, JansenMcWilliams $L$, et al. Age-specific incidence rates of myocardial infarction and angina in women with systemic lupus erythematosus: comparison with the Framingham Study. Am J Epidemiol 1997; 145:408-15.

23 Prior P, Symmons DP, Scott DL, Brown R, Hawkins CF. Cause of death in rheumatoid arthritis. Br J Rheumatol 1984:23:92-9.

24 Esdaile JM, Abrahamowicz M, Grodzicky T, Li Y, Panaritis C, du Berger R, ef al. Traditional Framingham risk factors fail to fully account for accelerated atherosclerosis in systemic lupus erythematosus. Arthritis Rheum 2001;44:2331-7.

25 Karrar A, Sequeira W, Block JA. Coronary artery disease in systemic lupus erythematosus: a review of the literature. Semin Arthritis Rheum 2001; 30:436-43

26 Lima DS, Sato EI, Lima VC, Miranda F Jr, Hatta FH. Brachial endothelial function is impaired in patients with systemic lupus erythematosus. J Rheumatol 2002:29:292-7.

27 Raza K, Thambyrajah J, Townend JN, Exley AR, Hortas C, Filer A, et al. Suppression of inflammation in primary systemic vasculitis restores vascular endothelial function: lessons for atherosclerotic disease? Circulation 2000;102:1470-2.

28 Dhillon R, Clarkson P, Donald AE, Powe AJ, Nash M, Novelli V, et al. Endothelial dysfunction late after Kawasaki disease. Circulation 1996;94:2103-6

29 International Study Group for Behçet's disease. Criteria for diagnosis of Behcet's disease. Lancet 1990;335:1078-80.

30 Chang HK, Cheon KS. The clinical significance of a pathergy reaction in patients with Behçet's disease. J Korean Med Sci 2002;17:371-4.

31 Walsh PS, Metzger DA, Higuchi R. Chelex 100 as a medium for simple extraction of DNA for PCR-based typing from forensic material. Biotechniques 1991; 10:506-13.

32 Chang HK, Kim JU, Cheon KS, Chung HR, Lee KW, Lee IH. HLA-B5I and its allelic types in association with Behçet's disease and recurrent aphthous stomatitis in Korea. Clin Exp Rheumatol 2001;19(suppl 24):S31-5.

33 Tesauro M, Thompson WC, Rogliani P, Qi L, Chaudhary PP, Moss Intracellular processing of endothelial nitric oxide synthase isoforms associated with differences in severity of cardiopulmonary diseases: cleavage of proteins with aspartate vs. glutamate at position 298. Proc Natl Acad Sci USA 2000;97:2832-5.

34 Wang XL, Sim AS, Wang MX, Murrell GA, Trudinger B, Wang J. Genotype dependent and cigarette specific effects on endothelial nitric oxide synthase gene expression and enzyme activity. FEBS Lett 2000;471:45-50.

35 Philip I, Plantefeve G, Vuillaumier-Barrot S, Vicaut E, LeMarie C, Henrion D, ef al. G894T polymorphism in the endothelial nitric oxide synthase gene is associated with an enhanced vascular responsiveness to phenylephrine. Circulation 1999:99:3096-8.

36 Wang XL, Mahaney MC, Sim AS, Wang J, Wang J, Blangero J, et al. Genetic contribution of the endothelial constitutive nitric oxide synthase gene to plasma nitric oxide levels. Arterioscler Thromb Vasc Biol 1997:17:3147-53.

37 Tsukada T, Yokoyama K, Arai T, Takemoto F, Hara S, Yamada A, et al. Evidence of association of the ecNOS gene polymorphism with plasma NO metabolite levels in humans. Biochem Biophys Res Commun 1998:245:190-3.

38 Oemar BS, Tschudi MR, Godoy N, Brovkovich V, Malinski T, Lüscher TF. Reduced endothelial nitric oxide synthase expression and production in human atherosclerosis. Circulation 1998;97:2494-8.

39 Lakhanpal S, Tani K, Lie JT, Katoh K, Ishigatsubo Y, Ohokubo T. Pathologic features of Behcet's syndrome: a review of Japanese autopsy registry data. Hum Pathol 1985:16:790-5.

40 Gül A. Behçet's disease: an update on the pathogenesis. Clin Exp Rheumatol 2001;19(suppl 24):S6-12

41 Kiraz S, Ertenli I, Calgüneri M, Ozturk MA, Haznedaroglu IC, Altun B, et al. Interaction of nitric oxide and superoxide dismutase in Behcet's disease. Clin Exp Rheumatol 2001;19(suppl 24):S25-9.

42 Evereklioglu C, Turkoz Y, Er H, Inaloz HS, Ozbek E, Cekmen M. Increased nitric oxide production in patients with Behçet's disease: is it a new activity marker? J Am Acad Dermatol 2002:46:50-4.

43 Er H, Evereklioglu C, Cumurcu T, Turkoz Y, Ozerol E, Sahin K, et al. Serum homocysteine level is increased and correlated with endothelin-1 and nitric oxide in Behçet's disease. Br J Ophthalmol 2002;86:653-7.

44 Orem A, Vanizor B, Cimsit G, Kiran E, Deger O, Malkoc M. Decreased nitric oxide production in patients with Behcet's disease. Dermatology 1999:198:33-6.

45 Mirza GE, Karakucuk S, Er M, Gungormus N, Karakucuk I, Saraymen R. Tear nitrite and nitrate levels as nitric oxide end products in patients with Behçet's disease and non-Behçet's uveitis. Ophthalmic Res 2001:33:48-51.

46 Creager MA, Gallagher SJ, Girerd XJ, Coleman SM, Dzau VJ, Cooke JP. Larginine improves endothelium-dependent vasodilation in hypercholesterolemic humans. J Clin Invest 1992;90:1248-53. 